\title{
Study on the College English Curriculum from the Perspective of General Education
}

\author{
Qun Li \\ Department of Foreign Language Teaching, Taishan University, Taian City, Shandong Province, 271000, China
}

\begin{abstract}
English is a very important skill. Learning English well is no longer an optional skill, it can improve the students' overall quality. Teachers should guide students to re-understand English from the perspective of general education so that students are willing to learn English well. This article reviews the domestic research on college English general education in the past 15 years so that researchers can have a better understanding of the present situation, development trend, existing problems and future development directions of general college English education in China. And from it ,we can get some useful implications for college English teaching.
\end{abstract}

Index Terms - general education, College English, courses

\section{THE REFORM BACKGROUND}

The new historical period put forward new requirements for college English teaching. For decades of reform and opening up, college English has basically focused on cultivating the students' comprehensive ability to use English and it has even been the only goal. It emphasizes the instrumentalists of English language. Although it is mentioned in the guidelines of English teaching that English teaching should improve the students' cultural awareness. It is bound to improve students' cultural accomplishment in English teaching to a certain extent. However, the humanistic nature of college English teaching has not been given due attention. At the same time, CET-4 and CET- 6 are treated as the only standard for testing university students' knowledge of English, our teaching thinking has been restricted and teachers can not give full play to their abilities, potentials and creativity. Students can not show their ability of autonomous and individualized learning. On the one hand, The Guidelines to College English Teaching defines the basic requirements for college English teaching. on the other hand, College English Teaching should also establish a classification system for college English teaching and encourage colleges and universities of different levels, types and regions to build a scientific and reasonable college English curriculum innovation system under the teaching guidelines. At present, the total credits of college students are limited, so many colleges and universities are reducing course credits, among these courses, the credits of college English is the first one to be reduced .Following this trend and with the continuous deepening of college English teaching reform, Many colleges and universities in our country are also gradually adjusting their college English curriculum. The percentage of general English teaching which aims at improving the students' language abilities decreased while the percentage of ESP and EGP has gradually increased. Optional courses after college English foundation course should be composed of EGP and ESP modules. EGP is divided into skills and humanities class. Academic type (ESP) is associated with a particular major that serves both students' professional and interdisciplinary learning. The new college English Curriculum System of the Trinity Mutual Inclusion of general English, EGP and ESP will become one of the directions for the development of college English teaching in China. Only three are compatible with each other and the ration of them is appropriate Only learning is combined with thinking and teaching students according to their aptitude, can a new situation in our college English teaching be established. The "College English Curriculum Standard" promulgated by the Ministry of Education in 2011 pointed out: "The setting of the college English curriculum is both instrumental and humanistic," and the notion of "instrumental and humanistic unity" is the brightest spot in the new English curriculum standard. On the one hand, "The Guidelines to College English Teaching" defines the basic requirements that college English teaching should meet; on the other hand, it tries to establish a classification system for college English teaching and encourage colleges and universities at different levels, types and regions to follow the teaching guidelines and school orientation, Students characteristics, personnel training specifications and other self-made personalized college English syllabus to build a scientific and reasonable university English curriculum innovation system. Curriculum reform should be an important part of college English teaching reform and a starting point to improve the quality of college English teaching. The new "College English Course Teaching Requirements" has a specific description for the curriculum, which shows the autonomy and individualism spirit. This research will realize the fundamental change from the teaching mode reform to the teaching content reform, and provide a new idea for deepening the reform of college English teaching. It is helpful to promote the overall improvement of teaching quality in higher education, and realize the goal of cultivating internationally-minded and innovative practical talents. This course system expands the field of college English teaching and enriches the content of college English teaching so as to help students to better inherit and spread Chinese culture. In particular, it can enhance the humanistic and international horizons of students and at the same time lay the 
foundation for students to further their study of professional foreign languages. It can stimulate students motivation of learning and cultivate students' autonomy and individualism. In a certain extent, it meets the needs of students in many aspects plays a practical and guiding role in constructing a system of innovative and practical talents with a combination of humanities and talents.

\section{Research Status of College English General EduCATion}

\section{Research Trends}

The domestic research on college English general education has been receiving attention since 2003, with only one related article published in this year. Up to 2007, there were 5 relevant articles published in these 5 years. However, the period between 2008 and 2017 witnessed a rapid development. In the four years, a total of 55 related articles were published.

\section{2. research content}

\subsection{College English general education}

In the thesis "General Education in College English", Chen Li proposed that general education should include foreign culture, history, literature and art, moral reasoning, natural science, social analysis and quantitative reasoning. Zhang Mei (2010) vigorously tapped the "general connotation" in college English courses to make up for the problems of college students' "emotional intelligence" and the lack of "manhood" through general education. Qi Tianli (2016) conducted a questionnaire survey and analysis on college English teaching and the current college English curriculum setting, and proposed some suggestions on the reform of college English curriculum settings that is adjusting the existing curriculum structure, setting up a variety of course contents and creating a new type Course model. Chen Yan and Liu Haiyan (2017) combined with the "3+1" college English teaching reform piloted by Jinan University in 2015 and explored the effective mode of integrating college English curriculum through the concept of general education.2.2.3 College English Teaching Reform from the Perspective of General Education

Jiang Hongxin (2004) first reviewed the history of general education in Western and Chinese universities in details and then reflected on the teaching of English majors and put forward the idea of teaching reform on how to cultivate English majors. Based on general education, Shanshan (2011) proposed that the study of background knowledge be the only way to improve the students' English proficiency and the specific way to improve the humane connotation of English teaching. Sun Shengping (2017) put forward it is an effective way to implement general education in college English education to carry out the student-centered interactive classroom teaching by making full use of multimedia. Feng Xinhua (2014) put forward the optional courses in college English is an effective way to achieve general education. Zhou Ying (2008) explored the specific ways of implementing general education of college English through teaching and educating people. Kang Zhifeng (2009) put forward countermeasures of changing the teaching idea and teaching mode on how to embody general education in college English teaching. Huang Gang (2010) explored the future integration of college English bilingual teaching and general education. Wang Erxia (2011) expounds the goal and reform ways of college English teaching under the perspective of general education which is building a diversified and distinctive curriculum system and strengthening the building of a culture-based curriculum system. Yu Zuying (2011) demonstrated that the second class of college English is an effective way to implement general education. Liu Wanting (2012, Gong Haoling (2013), Wang Lihui (2014) College English Teaching Reform from the Perspective of General Education), Gao Jiangling (2015) and Cui Yunbo (2017) proposed that teaching should be reformed on teaching objectives, teaching content, curriculum, teaching Model, and teaching method.

\section{2 research results}

During the nine years from 2008 to 2017, researchers in our country have shown great enthusiasm for research in college English general education and have made great strides in the research on general education of college English, but at the same time, There are also some shortcomings in the domestic research on college English general education: (1) From the point of view of research methods, most of the researchers only use literature review to study general education of college English, which lacks practical research methods. (2) From the point of view of research content, most of the researches are doing the repetitive research of college English teaching reform from the perspective of general education, and the research on innovation is obviously insufficient. (3) The formation of college English general education is not an overnight thing. At present, the research on this aspect basically adopts the horizontal research method and lacks the vertical follow-up and experimental research.

\section{TEACHING IMPLICATIONS}

College English courses include: college English course objectives, college English class schedule, college English compulsory courses, college English elective courses, college English follow-up courses and related factors affecting college English settings (teaching methods, teaching staff, English teaching materials, Evaluation system). We should reform the college English curriculum from the above perspective.

\section{Make clear the concept of general education}

At present, teachers and students in colleges and universities have the obscure concept of general education. They often confuse general education with quality education, professional education. Even when reforming higher education 
by using the concept of general education, they didn't carry out the overall design based on their own characteristics, but copied the teaching mode abroad, which didn't achieve the good effect. The first step of college English curriculum reform from the perspective of general education is to clarify the concept of general education. Colleges and universities should take strong measures to make teachers and students have a systematic and comprehensive understanding of general education. Undoubtedly, there are two sides to high education: utilitarianism and non-utilitarianism. Too much pursuit of utilitarianism in higher education will lead to deviations in the teaching philosophy of colleges and universities and to a large extent it will adversely affect students. General education is not only an educational concept, but also an educational view. It is also a brand new educational environment. It's proposal will guide high education to change and update the educational concept . The concept of general education is to train qualified and sound "perfect" human, which is also the ultimate goal of college education. This concept is the guidelines of the overall direction of college English curriculum. General education curriculum is the way to achieve the goal of general education. We can generalize the goals of college English curriculum from the perspective of general education as follows: the first one is to improve students' practical English ability, including listening and speaking ability. English, as an international language tool, is used for international communication and exchange. One of the goals of general education is to equip students with the basic knowledge and skills to adapt to social development. At present students are not satisfied with their own listening and speaking ability. The employers also think that students lack practical ability. If students learn English simply to find a job and earn a graduation credit, their enthusiasm to learn English will be greatly reduced. And they will be bored to learn English, which leads to the reduction of English practical ability. Second, Cultivate students' sentiments and improve their cultural literacy. General education is designed to enable students to acquire a high degree of understanding, tolerance and the pursuit of an elegant life through learning. Therefore, the study of English should incorporate the customs of western culture and the relevant contents of cultural differences at home and abroad to enhance students' cultural accomplishment. Third, Enhance English interdisciplinary knowledge learning. The goal of general education is to achieve the all-round development. In actual English communication, it needs not only English professional knowledge but also the knowledge in other fields. This requires that diversified subject knowledge must be integrated into the English curriculum so as to broaden students' knowledge.

According to Maslow's hierarchy of needs theory, human needs are divided into five levels, namely: Physiological needs, Safety needs, Love and belonging, Esteem, and Self-actualization. People only pursue high-level needs when their primary needs are met. For high education, professional education is a low-level requirement. It helps students acquire basic knowledge so that they can survive in society after they graduate. General education, on the other hand, is a high-level requirement that enables students to achieve Self-actualization. Therefore, under the new situation, we should change the traditional concept of English teaching and integrate general education into it. College English teaching should carry out the education idea of "people-oriented". On the basis of teaching basic knowledge, it should also emphasize on cultivating students' abilities of innovation, appreciation and reference of foreign culture, English thinking ability, practical ability and correct value orientation so that Students can form a reasonable structure of knowledge and ability and promote the all-round development so as to help the students become "perfect people" with coordinated development of moral, intellectual and physical aspects and a high social responsibility and noble sentiments.

\section{Build a new English curriculum system}

From the perspective of general education, college English should run through the entire university, but from the previous survey we can see that college English learning only stay in the basic learning stage. It is necessary to build a new English curriculum system. The new curriculum system consists of two levels: the implementation system and the security system. The implementation system includes: the course objectives, class schedule and course content. Security system includes teaching methods, teachers, English teaching materials and evaluation system. Class arrangements include the entire stage of the University, English compulsory courses should be set for the freshman and sophomore. For juniors elective courses should be set for them. For the senior English expansion development courses should be set. The courses consist of five parts: (1) basic courses (ie. basic listening, reading and writing course); (2) advanced courses (including advanced English reading, listening, writing and translation).The purpose is to improve the students' comprehensive English proficiency; (3)Development Courses (cultural literacy courses and cross culture communication courses, which includes English film appreciation, Western civilization and culture, Chinese and Western ceremonial culture and customs, the general introduction of British and American countries, the appreciation of famous British and American works, business English, etc.);(4) stealth courses; (5) online courses. In college English courses English courses, cultural literacy courses, listening and speaking courses, international courses and other cross-integration of English will be integrated to ensure that students' abilities in all aspects can be improved.

\section{Guide students to understand the latest information}

In the information technology society where science and technology is more and more developed, only the students have the latest information can they take the initiative in the process of communicating with others. For various reasons, if students only learn the information from the Chinese language, the students' access to information is very narrow. Students can learn more if they can read the information on the search engine directly in English. Teachers can make students aware of the importance of learning English in terms of getting students to know more.

For example, teachers can guide college students to read the following information: 
My favorite library is the Shenzhen University library which is near my home. It is a very big library. It has bright reading rooms, modern facilities, and efficient staff with gentle smile. These facilities and staffs provide us with a good condition to further their knowledge. The library has a collection of all kinds of books. Academic reading materials, novels, newspapers, magazines, etc. meet the needs of various local different people. You can obtain the updated information in almost all fields here. Till now the library owns 300000 copies of paper books, 280000 electronic books, 200 journals, 45newspapers. Electronic resources have a superstar digital library, scholar digital library, VIP database, Wan fang database and see Chinese newspaper network database, basically forming a "paper + digital resources" two layers of financial guarantee system. I also buy the digital library service and enjoy it a lot in the mobile device.

This is an introduction to Shen zhen library in English, if students can read English, they can learn the status of the construction of Shen zhen Library from another point of view. Students can go to the library to read their own books based on their needs. If students know a lot of important information are informed directly in English at present, they will be willing to learn English knowledge.

\section{Guide students to develop practical ability}

Practical ability of English includes speaking ability, reading ability, writing ability and so on. In this information age, people place higher demands on college students, which requires college students to solve all kinds of problems in their daily lives with the knowledge they have learned.

For example, teachers guide college students A and foreign students to communicate with B, college student B does not understand Chinese, she only speaks English. Two students exchange process is as follows:

A: What do you do in your spare time, Linda?

B: Well, I like shopping very much with my friends and I play basketball with them at the weekends.

A: Basketball?

B: Yes, I am fond of it a lot. What about you, Sam?

A: Me? Well, I like going to the cinema and the theater. And I like reading

B: Wow! You have a lot of hobbies.

A: Well, I like to enjoy my free time lonely not together with other people. And I plan to learn swimming, collecting coins which only one can do them. They can give me a lot of pleasure.

B: To be honest, I'd rather watch TV every night.

In this conversation, if Student A does not have solid basic English skills, he can not start a variety of topics with B.

Because she has a solid foundation in English, she can exchange her interests and daily life with B.

\section{Guide students to understand other countries' culture}

In this information society, college students often have to carry out cross-culture communication. in the actual exchange, students will find there are not only language barrier, but also cultural barrier. If Students communicate with others from their own point of view, there will be misunderstanding between them. This is due to historical reasons and geographical reasons. There are many cultural differences between our country and other countries. If you do not understand these differences, it is difficult for college students to communicate with other people.

In conclusion, when guiding college students to learn English, teachers should make university students understand that learning English well can improve themselves and their overall quality from the perspective of general education.

\section{Take a variety of teaching methods}

Some scholars once said that it is more important how to teach knowledge than to what kind of knowledge should be taught. The goal of college English teaching is that students can not only have a reasonable knowledge and ability structure by learning English, but also can observe and think about the world using their unique thinking patterns. At present, English teaching in colleges and universities is a "one-way inculcation-oriented teaching" led by teachers. Students have low participation. In this way, students can really learn basic knowledge, but it is also easy to make students feel bored of learning which is not helpful to improve the students' cultural attainment and the innovative ability. Furthermore, due to college expansion of enrollment, English classes in some schools have become a big classroom of one or two hundred people, making English teaching effects unsatisfactory. Teachers lay much stress on the basic knowledge, which is not in conformity with the requirement of employers to pay attention to the practical ability of English. We should change this traditional English teaching mode so that teachers become the designers of the classroom and the students become the center of the classroom. English teaching in colleges and universities should promote "heuristic education in English" so that students can take the initiative to learn English and improve their English thinking ability and flexibility. Teachers can assign tasks to students in advance, for example, the students need to systematically interpret the differences between American culture and Chinese culture through reading relevant materials to cultivate students' thinking ability and oral expression ability. Students can also imitate the English lessons and write a similar article, which not only can consolidate the knowledge, but also enhance students' writing ability. In the English class, a variety of teaching methods such as role playing, game interaction, scene simulation and group discussion are used to activate the classroom atmosphere, eliminate students' fear of the English classroom, improve students' classroom participation and create an environment for students' interpersonal communication. And it can also promote communication between students and teachers and enhance the team spirit and cohesion of classes, develop students 'creative ability, stimulate students' interest in learning and help students learn how to behave well.

\section{Reform English teaching materials}


Although there have been many changes in college English textbooks over the past two decades, there are few teaching materials that have had a substantial effect on college English teaching. Many of the textbooks have no definite teaching goal and lack comprehensiveness and practicality. As a base to achieve the goal of English teaching, English teaching material has a direct impact on the students' interest and motivation in learning English, which is a key factor in deciding the success or failure of English teaching. Firstly, the teaching materials must be real materials that can clearly reflect the economic conditions and religious cultures of the countries in Europe and the United States so that students can obtain real information about English and American countries from English learning. The updating of textbook should also keep up with the pace of the times. Secondly, we should select the article from the perspective of the needs of students. Students are more interested in humanistic literacy, entertainment and popular science articles, which should be included in order to stimulate students' interest in learning and improve their cultural accomplishments. Finally, articles in English textbooks should include interdisciplinary knowledge, such as national trade, business etiquette, travel English, etc. Teaching materials must have depth and breadth which can trigger the students' curiosity, enhance students' cross-cultural awareness and enhance students' comprehensive quality and the ability to accept new information. Besides, listening comprehension materials in college English also lack new ideas, and there are many out of dated essays as listening comprehension texts. Oral English textbooks and translation textbooks are still a "black hole" in college English textbooks. They should prepare translating textbooks that are suitable for students 'needs and enhance students' English practical ability to establish a correct outlook on life and values and improve students' personality.

\section{REFERENCES}

[1] Chen Yan, Liu Haiyan. (2017). Studies on the integration of college English curriculum through the concept of general education. Journal of Shandong Radio and TV University, 3, 67-72.

[2] Cui Yunbo. (2017). College English follow-up course design research and theoretical exploration. Language, 4, $102-106$.

[3] Feng Xinhua. (2014). On the Curriculum Design of College English Electives - From the Perspective of General Education. Hei longjiang Higher Education Research, 11, 102-106.

[4] Gao Haoling(2013). General education and college English teaching reform. Jilin Provincial Institute of Education Report, 7 , 79-83.

[5] Huang Gang. (2010). Demand Analysis and English Education Curriculum. Teaching Research, 9, 66-69.

[6] Jiang Hongxin. (2004). General Education and the Cultivation of English Majors. Journal of Sichuan International Studies University, 6, 53-59.

[7] Kang Zhifeng. (2009). College General Education and Cultivation of Complex Talents in English Majors. Journal of Sichuan International Studies University, 4, 46-47.

[8] Liu Wanting. (2012). Comprehensive English Curriculum Reform and Construction under the Concept of Humane Liberal Education. Journal of Hubei Jiao Tong University, 2, 35-40.

[9] Qi Tianli. (2016). Survey and Reflection on College English Curriculum from the Perspective of General Education .Modern Education Management, 9, 120-125.

[10] Shanshan. (2011). Comprehensive English Curriculum Reform and Construction under the Concept of Humane Liberal Education. Journal of Hubei Jiao Tung University, 2, 96-100.

[11] Sun Shengping. (2017). General education in college English classroom teaching. College English, 2, 135-138.

[12] Wang Lihui. (2014). College English Teaching Reform from the Perspective of General Education. Huaihua University Daily, 8 , 67-69..

[13] Wang Erxia, Yu Zuying. (2011). Analysis of Current Situation of College English Teaching and Reform Ideas. Advanced Architectural Education, 17, 16-19.

[14] Wu Dingmin. (2003). College English and General Education. Zhenjiang College, 4,156-161.

[15] Zhang Mei. (2010). Research and Practice of English Teaching Reform from the Perspective of General Education Concept. College English, 3, 78-82.

[16] Zhou Ying. (2008). Investigation of College English Learners' Learning Needs and Its Enlightenment. Foreign Language Teaching, 3,111-114.

Qun Li was born in Taian city, Shandong province of China in 1978. She received her Master's degree in linguistics from Shandong University, China in 2008. She is a member of the Chinese Association of Foreign Language Teachers. 